\title{
The Reception of Sappho's Brothers Poem in Rome
}

\author{
Llewelyn Morgan
}

Sappho boasts a higher profile in Roman poetry than any other of the Greek canon of lyrists, as we can tell even despite the tiny proportion of her nine Alexandrian books of poetry that survives. ${ }^{1}$ This implies high familiarity with her poetry amongst Roman readers, a familiarity that can be illustrated from a striking range of Latin authors: not only Catullus and Horace, but also Plautus, ${ }^{2}$ Valerius Aedituus, ${ }^{3}$ Statius, ${ }^{4}$ and Juvenal. ${ }^{5}$ Familiarity of this kind did not of course preclude the Sappho with whom Roman writers and readers engaged becoming in important respects a caricature of the author of those nine metrically and stylistically diverse books. Given the nature of literary history, indeed, radical distortion was inevitable. Thus the metre of the first book of Sappho, the Sapphic stanza, came to be seen as her characteristic metre, whether the decision of the Alexandrian editors reflected a preexisting perception, or fixed that perception itself; and generalizing accounts of her poetic style were written that could not truly apply across her entire oeuvre. Pseudo-Demetrius, discussing poetic $\chi \alpha \dot{\alpha} ı \varsigma$, asserts that 'Charm may reside in the subject matter, such as gardens of the nymphs, marriage songs, loves, Sappho's poetry in gen-

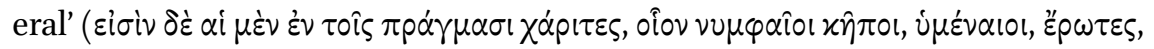
ઠ̋ $\lambda \eta \dot{\eta} \Sigma \alpha \pi \varphi \circ \hat{\varsigma} \varsigma \pi$ oí $\sigma \varsigma \varsigma) .^{6}$ Even when illustrating the diversity of Sappho's work, Pseudo-Demetrius (On Style 166-167) manages to imply that it is the poetry she wrote 'on love or spring or the halcyon' which is most characteristically hers:

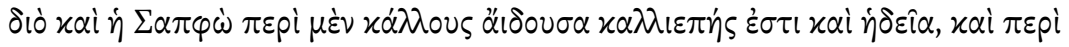

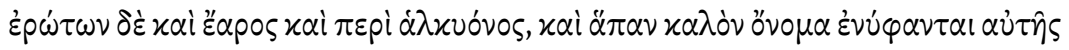

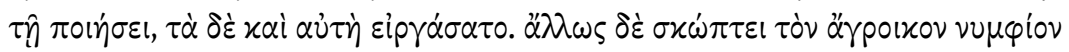

1 My thanks to the editors André Lardinois and Anton Bierl for their thoughtful comments on this paper.

2 Traill (2005).

3 Courtney (1993) 72-74: a uetus poeta according to Aulus Gellius 19.9.10, and presumably (from the company he keeps in Gellius) with a floruit in the late second century вс.

4 Morgan (2010) 189-199.

5 Edwards (1991).

6 Eloc. 132 = test. 215 .

(C) LLEWELYN MORGAN, 2016 | DOI: 10.1163/9789004314832_015

This is an open access chapter distributed under the terms of the Creative Commons Attribution-

Noncommercial 3.o Unported (CC-BY-NC 3.0) License. 




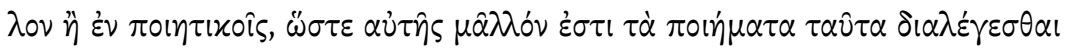

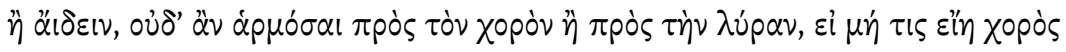
$\delta เ \alpha \lambda \varepsilon \kappa \tau i x o ́ \varsigma$.

This is why Sappho sings of beauty in words which are themselves beautiful and attractive, or on love or spring or the halcyon. Every beautiful word is woven into the texture of her poetry, and some she invented herself. But it is in a very different tone that she mocks the clumsy bridegroom and the doorkeeper at the wedding. Her language is then very ordinary, in the diction of prose rather than poetry; so these poems of hers are better spoken than sung, and would not suit the accompaniment of a chorus or lyre-unless you could imagine a chorus which speaks prose.

An awareness of the stylistic breadth of Sappho's actual poetry here coexists, it seems, with a privileging of Sappho's beautiful verse about beauty as representative of her art: her scoptic verse, in contrast, is barely even poetic, let alone lyric. Certainly the Roman-era reception of Sappho was apt to stereotype her verse as love poetry with a delicacy of expression to match its content. Perhaps the most striking illustration of the "essentialized" Sappho of her later classical tradition is the prominence of fr. $3^{1}$ in her Latin reception, ${ }^{7}$ an individual poem in Sapphic form and concerned with love which is preserved for us by Pseudo-Longinus (On the Sublime 10.1-3) as an encapsulation of Sappho's poetic art.

Rome's Sappho also came with all the accretions generated by the very celebrity of her poetry, a notable example being the story of her infatuation with Phaon, at the heart of which is presumably some kind of distortion of a poem expressing her religious devotion, or perhaps Aphrodite's devotion, to Adonis. ${ }^{8}$ Comedy seems to have played a crucial role in crystallizing this set of stories about the poet. Yet even a figure so radically reshaped by tradition as the Roman Sappho has the potential to reflect illuminatingly back on the archaic Sappho; that at any rate is the core of my argument in this article.

A particularly egregious illustration of the distortions visited on Sapphoand yet at the same time a source of rather precious information-is rep-

7 Morgan (2010) 196-198; see Plut. Mor. 763a.

8 Bowra (1961) 213-214; Detienne (2007) 103; Nagy (1973/199ob); Kivilo (2010) 179-182. For the ancient biography of Sappho, and its sources, see Lefkowitz (2012) 41-43; Kivilo (2010) 167200. 
resented by Heroides 15, the Epistula Sapphus. This poem, purporting to be Sappho's letter to Phaon far away in Sicily, is attributed to Ovid, but its true authorship is hotly contested. Contested it will no doubt remain, since each case, for or against Ovid as the author, has its cards to play, and neither lands a knockout blow. ${ }^{9}$ Richard Tarrant's trenchant assessment of the poem's quality, 'a tedious production containing hardly a moment of wit, elegance or truth to nature, ${ }^{10}$ is not without foundation, but what matters for my purposes is that the author of Sappho's letter to Phaon, whoever it might be and whatever talent we might attribute to him, was familiar with Sappho's poetry: Peter Knox offers plentiful evidence of that. ${ }^{11}$

One moment in the Epistula Sapphus (=Es) that is not highlighted by Knox, but which is potentially of significant interest in this connection, is when Sappho addresses the women of Lesbos at lines 199-202:

Lesbides aequoreae, nupturaque nuptaque proles, Lesbides, Aeolia nomina dicta lyra,

Lesbides, infamem quae me fecistis amatae, desinit ad citharas turba uenire meas!

Island-dwelling women of Lesbos, girls wed and to-be-wed, women of Lesbos, names spoken by my Aeolian lyre, women of Lesbos, my love for whom made me notorious, throng no longer to my songs.

The notion that the female protagonists of Sappho's love poetry were girls at the point of marriage, which seems to be the clear implication of nupturaque nuptaque proles, corresponds to one modern scholarly view, represented by the articles of François Lasserre and André Lardinois, for example; ${ }^{12}$ but it is a controversial one. ${ }^{13}$ Whether or not the idea that marriage is an important context for Sappho's love poetry has validity for the seventh century вс, however, there is a plausible argument to be made that this was how the Romans saw it. The two poems of Catullus in Sapphics, poems 11 and 51, are commonly understood

\footnotetext{
9 Tarrant (1981); Rosati (1996); Bessone (2003); Knox (1995) $12-14$.

10 Tarrant (1981) 134-135.

11 A general statement at Knox (1995) 14: 'it is clear that the author of the $E s$ knew Sappho's poetry.' See also Knox's notes at ES 31-40, 61, 112, and 154, and Woodman (2002) 59 .

12 Lardinois (1994); Lasserre (1974). See also Bierl, ch. 14, this volume.

13 Parker (1993). See also Bowie and Schlesier in this volume.
} 
as marking the beginning and end of the poet's affair with 'Lesbia', but Roland Mayer has observed that Catullus constructs his farewell to Lesbia in poem 11 on the model of a Roman divorce formula: ${ }^{14}$ it would allow an elegantly cohesive reading of the two poems, to put it no more strongly, if the start of the relationship in poem 51 , by virtue of his close imitation of the content and form of Sappho fr. 31 , lent it marital associations..$^{15}$

Before we pursue the testimony of the Epistula Sapphus any further, I would like to introduce the Brothers Poem to my discussion of the Roman reception of Sappho, starting from the clear evidence that a poem new to us was very familiar to Horace, and left a discernible mark on his lyric poetry.

An early observation, mentioned already in Dirk Obbink's $T L S$ article, ${ }^{16}$ was the allusion to Sappho's poem in Horace's Odes 1.9, the Soracte Ode. The points of similarity, and some of the implications of the allusion, are laid out by Tom Phillips, ${ }^{17}$ but most striking is the close imitation of Sappho's lines 9-10, $\tau \dot{\alpha} \delta^{\prime}$

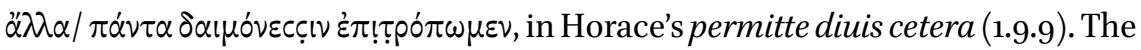
exhortation is enforced in both poets with a statement of the gods' power over human prosperity, expressed through the metaphor of sudden positive changes in the weather. Phillips also draws out the significance that this of all Horace's odes should be the site of so overt an allusion to Sappho, the last of the socalled Parade Odes, where Horace finally settles on the signature metre of his collection, and by implication the key ethos animating his lyric verse: Alcaics and Alcaeus, not Sappho. ${ }^{18}$

But another of Horace's odes, equally prominent in its own way, also displays a debt to the Brothers Poem. ${ }^{19}$ This is Ode 3.29, a summation of his lyric philosophy (as Eduard Fraenkel most eloquently shows ${ }^{20}$ that occupies an extremely conspicuous position at the end of the three-book collection: if Ode 3.30 may be understood as a detachable postscript, 3.29 is its summation. There isn't the same precision of verbal imitation here as in permitte diuis cetera, but we do have another emphatic cetera, again representing that predominance of things that lies beyond our ability to control; and there is very similar weather imagery. Above all, however, Ode 3.29's view of life adopts an overtly economic form (something that is not so visible in Ode 1.9), and ultimately finds itself in the

\footnotetext{
14 Mayer (1983).

15 Morgan (2010) 200-212.

16 Obbink (2014a).

17 Phillips (2014).

18 A notion developed in Lyne (2005) with consideration of Odes 1.9-11.

19 Morgan (2014) is a very preliminary version of the argument that follows.

$20 \quad$ Fraenkel (1957).
} 
environment where the Sappho fragment starts, and Ode 1.9, too intent on Mt Soracte, never ventures, the unpredictable world of Mediterranean maritime trade:

\section{quod adest memento}

componere aequus; cetera fluminis ritu feruntur, nunc medio aequore cum pace delabentis Etruscum in mare, nunc lapides adesos

stirpisque raptas et pecus et domos uoluentis una, non sine montium clamore uicinaeque siluae, cum fera diluuies quietos

inritat amnis. ille potens sui laetusque deget cui licet in diem dixisse: 'uixi': cras uel atra nube polum Pater occupato

uel sole puro; non tamen inritum quodcumque retro est efficiet neque diffinget infectumque reddet quod fugiens semel hora uexit.

Fortuna saeuo laeta negotio et ludum insolentem ludere pertinax transmutat incertos honores, nunc mihi, nunc alii benigna.

laudo manentem; si celeris quatit pinnas, resigno quae dedit et mea uirtute me inuoluo probamque pauperiem sine dote quaero.

non est meum, si mugiat Africis malus procellis, ad miseras preces decurrere et uotis pacisci, ne Cypriae Tyriaeque merces 
addant auaro diuitias mari;

tunc me biremis praesidio scaphae

tutum per Aegaeos tumultus

aura feret geminusque Pollux.

Be sure to deal equitably

with what is at hand. As for the rest, it flows by like a river, now gliding calmly in mid-channel down to the Tuscan sea, now tumbling eroded rocks

and uprooted trees and cattle and homes all together, with a din from the mountains and forest beside it as the wild deluge stirs up

its tranquil waters. That man will be happy and in control of his life who every day can say 'I have lived'. Tomorrow let Father Jupiter fill the sky with black cloud

or with clear sunlight, but he will not render invalid what is behind us, nor alter or make undone what once the racing hour has brought.

Fortune is happy in her cruel work and plays her proud game unrelentingly, shifting her fickle affections, one moment kind to me, the next to another.

I praise her while she's with me. If she shakes out her swift wings, I resign what she gave, wrap myself in my virtue, and court honest Poverty, who brings no dowry.

It is not my way, if the mast creaks in African gales, to resort to pitiful pleading and bargaining with prayers so my Cypriot and Tyrian cargo 
not add its wealth to the greedy sea;

When that time comes, the breeze and twin Pollux will carry me safe in the fortress of my two-oared dinghy through the Aegean storms.

I would add to parallels already noted that Horace's attitude to prayer here reflects Sappho's rather closely: I follow Franco Ferrari and René Nünlist in seeing a subtle but important contrast between the two references to Charaxos' ship; the ship full of merchandise ( $\nu$ âi cं่v $\pi \lambda \eta \dot{\eta} \alpha$ ) in line 2, and the straight-

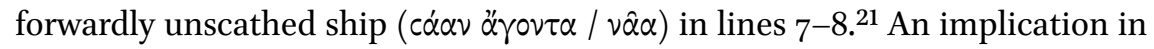
Sappho's poem is that while one might sensibly pray for safe return, prosperity is something entirely beyond our capability to influence. This is similar, I think, to Horace's separation of personal survival from the wealth which it is not his way to plead that the gods preserve.

If this reading has any force, the debt of this ode to Sappho is as remarkable as that of 1.9, and it is potentially further fuel for the perennial controversy as to the truth of Horace's lyric claim of a special affiliation to Alcaeus. ${ }^{22}$ But I conclude with a brief backward look at Sappho's poem from a Roman perspective. The account of Sappho's life and misfortunes, including the behaviour of Charaxos, in the Epistula Sapphus is as follows $(61-70)$ :

sex mihi natales ierant, cum lecta parentis

ante diem lacrimas ossa bibere meas.

carpsit opes frater meretricis captus amore

mixtaque cum turpi damna pudore tulit.

factus inops agili peragit freta caerula remo,

quasque male amisit, nunc male quaerit opes.

me quoque, quod monui bene multa fideliter, odit;

hoc mihi libertas, hoc pia lingua dedit.

et tamquam desint, quae me sine fine fatigent, accumulat curas filia parua meas

Six birthdays has passed for me when I gathered the bones of my father, dead before his time, and they drank my tears.

My brother squandered his/our wealth, overwhelmed with love for a harlot,

\footnotetext{
21 Ferrari (2014) 3-4; Nünlist (2014). See also Bierl (ch. 14), Lardinois and Stehle in this volume.

22 I am thinking especially of the argument of Woodman (2002).
} 
and suffered financial loss along with foul shame.

Reduced to poverty he traverses the blue seas with nimble oar, and the wealth he lost discreditably, he now discreditably earns. Me too he detests for the devoted advice I have often given him: this my candour has brought, this my loving words.

And as if there were a lack of things to weary me without cease, my little daughter heaps woes on my woes.

This passage repays close reading, and I preface my commentary by the mere observation that the missing first stanza of the Brothers Poem is reconstructed (explicitly exempli gratia, I should say) by Obbink partly by means of $E S$ 6162. ${ }^{23}$ Sappho is describing her own grauis fortuna (59), in which Phaon is the latest in a long sequence of misfortunes. At six she lost her father, but then her eldest ${ }^{24}$ brother, who will have succeeded to the role of head of the family, squandered the family wealth on Doricha, incurring the shame of a relationship with a meretrix in the process: carpsitopes is Bentley's conjecture, ${ }^{25}$ but the focus on the financial quandary in which he, and by extension his family, found themselves is clear enough from what follows. We then hear of Charaxos' efforts to recover his fortune, and a natural way to interpret line 66, quasque male amisit, nunc male quaerit opes, is that his wealth acquisition is as morally questionable as his expensive entanglement with Doricha. Peter Knox and David Campbell tentatively suggest that the discreditable means by which Charaxos recouped all the money he spent on Doricha/Rhodopis was piracy, ${ }^{26}$ but need it actually be anything more than trade? Sappho's status as an aristocrat, and her poetry as an expression of quintessentially aristocratic values, is well established, and scholars have also discerned in her poetry a concomitant antipathy to the emergent bourgeoisie that threatened the political dominance enjoyed by Sappho's class. Thus Holt Parker talks of the 'conflict of the older aristocratic families against the new and vulgar rich' we can glimpse in Sappho's poetry, and cites fr. 55, said by Stobaeus 3.4.12 to be addressed to an uneducated woman, and by Plutarch, Moralia 145 f-146a to a wealthy woman; ${ }^{27}$ citing the same fragment, Margaret Williamson opines that '[i]f poetic skill was a badge of social accomplishment for aristocratic women as it certainly was for men, then this poem may be as intimately bound up in the politics of Lesbos as

23 See Obbink, ch. 1, this volume.

24 Sappho test. 252 (P. Oxy. 1800).

$25 \operatorname{Knox}(1995)$ ad loc.

26 Knox (1995) 292; Campbell (1982a) 16 n. 1.

27 Parker (2005) 12-13. See also Martin, this volume. 
any of Alcaeus' tirades, pitting aristocratic culture against mere wealth'. ${ }^{28}$ The likely sources of this "mere wealth" in trade and commerce might easily have rendered Charaxos' mercantile activities, to Sappho's refined aristocratic sensibilities, quite dishonourable enough. Kurt Raaflaub in this volume suggests that an involvement with trade, so long as it fell short of the fully professional, 'was compatible with Greek elite values'. But does the Epistula Sapphus represent Charaxos' mercantile activities as less than all-consuming and "professional," as anything other than a career choice driven by dire necessity?

What is certainly not hard to discern in Sappho's oeuvre as a whole is the differential treatment of the brothers Charaxos and Larichos, the former criticised, the latter praised, the former a merchant, the latter growing up in the aristocratic milieu of Mytilene (test. 203), serving as a cupbearer in the town hall of Mytilene. A suggestion of the same may be found in the Brothers Poem, where it seems that Charaxos' commercial success, for the speaker at least (the addressee seems to think differently), is of no moment compared with the hope of Larichos growing to be an àvnp: in Obbink's words, 'a settled member of the leisured, aristocratic class,', ${ }^{29}$ 'an $\alpha$ ' $\nu \eta$ in all senses', presumably including 'aristocratic demeanor, noble marriage, transfer of wealth, and production of legitimate offspring. ${ }^{30}$ The speaker seems mainly concerned with the success of her aristocratic clan, investing in Larichos, not Charaxos, her hopes that it will flourish, under Larichos' leadership.

Whether coincidentally or not, Horace in Odes 3.29 also promotes an ethos disparaging trade in favour of philosophical detachment which carries more than a hint of aristocratic anti-mercantile prejudice. At any rate, we have seen a range of ways in these pages in which Latin literature impinges on the study of Sappho. For all Horace's protestations, Sappho proves once again as significant a presence in the texture of his lyric poetry as his fondness for the Sapphic stanza might otherwise suggest, while the contribution to the Sapphic tradition represented by Heroides 15 poses a dilemma that goes to the heart of an intriguing question: the Epistula Sapphus, in its own second-rate fashion, engages gamely enough with that tradition; but as well as evidence for a Sappho reshaped to suit the cultural predilections of a Roman literary public, can it also help us to reconstruct and comprehend in their earliest performance context the Sapphic fragments that continue serendipitously to come our way?

\footnotetext{
$28 \quad$ Williamson (1995) 86.

29 Obbink (2014b) 34.

$30 \quad$ Obbink (2014b) 35 .
} 